\title{
PENSION FUND RESTORATION POLICY IN GENERAL EQUILIBRIUM
}

\author{
Pim B. Kastelein \\ University of Amsterdam \\ WARD E. ROMP \\ University of Amsterdam
}

\begin{abstract}
When the financial positions of pension funds worsen, regulations prescribe that pension funds reduce the gap between their assets (invested contributions) and their liabilities (accumulated pension promises). This paper quantifies the business cycle effects and distributional implications of various types of restoration policies. We extend a canonical New-Keynesian model with a tractable demographic structure and, as a novelty, a flexible pension fund framework. Fund participants accumulate inflation-indexed or non-indexed benefits and funding adequacy is restored by revaluing previously accumulated pension wealth (Defined Contribution (DC)) or changing the pension fund contribution rate on labor income (Defined Benefit (DB)). Economies with DC pension funds respond similarly to adverse capital quality shocks as economies without pension funds. DB pension funds, however, distort labor supply decisions and exacerbate economic fluctuations. While DB pension funds achieve intergenerational risk-sharing, welfare analyses indicate that the negative effects of the induced distortions are sizeable.
\end{abstract}

Keywords: Pension fund, Regulation, New-Keynesian model, Intergenerational risk-sharing

\section{INTRODUCTION}

The financial positions of pension funds worsened worldwide during the financial crisis of 2008 and the ensuing sovereign debt crisis of 2009. Not only did these crises depress asset values, subsequently low interest rates inflated the discounted value of pension fund liabilities. Pension funds were left with a funding deficit since the present discounted value of accumulated pension promises of fund participants far exceeded the value of invested contributions. Federal Reserve Flow of Funds data indicate that U.S. retirement fund assets were virtually cut in half between 2007 and 2009 as a result of the 2008 financial crisis [Treasury (2012)] and estimations by Novy-Marx and Rauh (2011) imply that the funding gap of

\footnotetext{
This work is part of the research project "Pension funding, housing wealth and macroeconomic demand" with project number 406.16.530, which is partly financed by the Netherlands Organization for Scientific Research (NWO). Address correspondence to: Pim B. Kastelein, Amsterdam School of Economics, University of Amsterdam, Roeterstraat 11 E3.24, 1012 WX Amsterdam, The Netherlands. e-mail: p.b.kastelein@uva.nl.
}

(C) 2019 Cambridge University Press. This is an Open Access article, distributed under the terms of the Creative Commons Attribution licence (http://creativecommons.org/licenses/by/4.0/), which permits unrestricted re-use, distribution, and reproduction in any medium, provided the original work is properly cited. $1469-8056 / 181785$ 
U.S. state-sponsored pension plans in 2008 was as large as 3.23 trillion dollars. The experience in other countries has been similar. Laboul (2010) highlights that the estimated pension fund liabilities of 2100 exchange-listed companies from OECD countries were on average roughly $25 \%$ larger than their assets in 2008 and 2009.

If pension funds are to avoid exhausting their assets, funding deficits need to be covered through the implementation of suitable restoration policies. Regulations generally stipulate that pension funds should achieve funding adequacy in order to avoid shifting the costs to future generations. However, there are various ways in which this can be done and in this paper we consider Defined Contribution (DC) systems which write down the value of pension promises to fund participants in order to bring the liabilities of pension funds closer to assets and Defined Benefit (DB) systems which increase the required contributions paid by current and future workers to bring the assets of pension funds closer to liabilities. The 2013 Pensions at a Glance report of the OECD shows that there is little consensus among pension funds and regulators with regard to the preferred way of restoring the financial adequacy of pension funds: between 2009 and 2013 all OECD countries have reformed their pension systems, but the measures taken differ widely. This heterogeneity undoubtedly relates to the fact that different types of restoration policies have different distributional consequences and different implications for macroeconomic performance, which is especially relevant when the economy is in a state of crisis. Unfortunately, much of the pension economics literature studies pension funds only from a long-term perspective [see for instance Gollier (2008) and Beetsma and Bovenberg (2009)] which inherently abstracts from effects materializing at business cycle frequencies. With more countries shifting away from Pay-As-You-Go pension systems to funded systems (motivated by population ageing) and the recently experienced sensitivity of pension funds to financial crises, insights about sound pension fund policy at a business cycle frequency are essential.

This paper aims to fill this gap in the literature and thus aims to provide an assessment of the business cycle effects and distributional consequences of pension fund restoration policies. To do so, we extend a canonical NewKeynesian, closed economy, dynamic general equilibrium model with a tractable demographic structure and a flexible pension fund framework. We build on the overlapping generations framework of Gertler (1999), who introduces lifecycle behavior in a business cycle model. The production sectors of our model are inspired by Kara and von Thadden (2016) and incorporate investment adjustment costs, imperfect competition in the retail sector, and nominal Calvo (1983)-pricing rigidities. As a novelty, we extend the pension fund framework of Romp (2013) and incorporate it into our model. This framework embeds various types of pension funds observed in reality, depending on the specific parameterization, and allows for the accrual of inflation-indexed or non-indexed pension wealth. The pension fund sets the restoration policy (given by the contribution rate on labor income, the accumulation rate of the annuity and a revaluation instrument) depending on its financial position. 
From a modeling perspective, this paper improves upon the pension fund design literature along various dimensions. Firstly, the nominal rigidities and nominal accrual of pension benefits allow for a comparison of fully indexed and non-indexed pension funds that was not possible in the existing literature which does not consider nominal rigidities. Secondly, the demand side of the economy is enriched compared to Romp (2013), who does not conduct a welfare analysis because agents have a linear utility structure and are hand-to-mouth consumers with no intertemporal reallocation in response to shocks. Thirdly, this paper focuses on the short-term phenomenon of restoration policy, while others employ long-term OLG models that abstract from distortions and market imperfections materializing at business cycle frequencies. Fourthly, others tend to consider open economy models in which the interest rate is set exogenously, while the interest rate in our model is determined endogenously.

We consider a Gertler and Karadi (2011)-type unexpected capital quality shock which evaporates a fraction of the capital stock and leaves the pension fund with a funding gap that needs to be closed. We find that when individuals accumulate real pension benefits a DC economy behaves similarly to a Laissez-Faire economy, because the writing down of previously accumulated pension wealth has a similar effect on total lifetime wealth as losing private financial wealth. In a DB economy, there are two counteracting forces at work. On the one hand, the pension fund increases the contribution rates on labor income and distorts labor supply. On the other hand, the pension fund redistributes wealth toward the group of individuals that has a higher marginal propensity to consume out of wealth (MPCW), which is important in a demand-driven model. We find that the former effect is the strongest and that the DB pension fund exacerbates economic fluctuations. When individuals accumulate nominal pension benefits, the shock leaves the pension fund with a surplus due to ensuing inflation in the medium term as the economy recovers. The DB pension fund then subsidizes labor supply, which dampens economic fluctuations.

The recovery from the unexpected capital quality shock requires the pension fund to distribute welfare losses (or gains) to different groups of individuals and generations. We calculate equivalent variations to assess the welfare effects for three groups of individuals. Retirees are vulnerable to a loss of pension wealth, but are insensitive to distortions on the labor market, and therefore prefer the pension system that maximizes their pension wealth. The workers who have already accumulated pension wealth in the period the shock materializes dislike labor supply distortions, but also dislike losing their pension wealth because it is the only available asset that yields a return conditional on the lifecycle stage of the individual. The future generations prefer the pension system that brings about the most favorable labor market conditions. We find that there is no unanimous agreement between workers, retirees, and future generations about optimal pension fund design.

While DB pension funds (which have been studied in environments without nominal rigidities) are generally considered to be ex ante welfare improving 
because they bring about intergenerational risk-sharing [see Beetsma and Romp (2016) for an overview] and increase the risk-taking capacity of the economy [Gollier (2008)], our results show that the induced distortions of such systems are sizeable when nominal rigidities are present. This is in agreement with Beetsma et al. (2013) and Romp (2013) who find that DB pension funds induce significant labor supply distortions, but Bonenkamp and Westerhout (2014) and Draper et al. (2017) argue that the welfare gain from intergenerational risk-sharing dominates the cost of labor supply distortions. We show that, in the presence of nominal rigidities, inflation-indexed DB pension funds cause workers to be negatively affected by adverse shocks, while workers are less positively affected by positive shocks. As a result, the appeal of inflation-indexed DB pension funds (which are closest in design to the pension funds that have been studied in environments without nominal rigidities) is dampened. Thus, the message of Gollier (2008), which stresses that maintaining intergenerational risk-sharing through pension funds after poor capital market performance requires strong government commitment (because younger generations will want to abolish it), becomes even more of a concern in a New-Keynesian setting.

This paper is structured as follows. Section 2 describes the workings of the pension fund, the decision problems of retirees and workers, the supply side of the economy, and the actions of fiscal and monetary authorities. Section 3 discusses the calibration of the model, analyzes the effects of pension fund restoration policy on the rest of the economy, and discusses the welfare implications after an unexpected shock to capital quality. Section 4 concludes. Technical details are delegated to the Supplementary Appendix.

\section{THE MODEL}

The economy is populated by a pension fund, workers, retirees, capital producers, final, intermediate and retail good producers, and a central bank. Workers face a constant probability of becoming retired and retirees face a constant probability of passing away. We invoke Risk Neutral Constant Elasticity (RINCE) preferences which restrict workers and retirees to be risk neutral, but which allow them to have any arbitrary intertemporal elasticity of substitution. This class of preferences yields that all workers and retirees that are in the same lifecycle stage consume an identical fraction of their total lifetime wealth, irrespective of their age or the amount of wealth they possess, which facilitates aggregation despite the heterogeneity of workers and retirees at the micro-level. In each period, workers and retirees decide how much to consume, labor to supply, and to save. When earning labor income, individuals pay a mandatory contribution to the pension fund and in return accumulate pension wealth in the form of an annuity that is inflation-indexed or non-indexed. The annuity, also referred to as the per-period pension benefit, is paid out by the pension fund each period in which the individual is retired. The size of the annuity is not constant over time, but changes when individuals pay pension contributions and when the pension fund writes down or 
marks up the value of previously accumulated pension wealth. The pension fund sets the contribution rate on labor income, the accumulation rate of the annuity, and the revaluation instrument (which together comprise its restoration policy) depending on its financial position. The production sectors of the economy are of the New-Keynesian form and subject to investment adjustment costs, imperfect competition in the retail sector, and nominal Calvo (1983)-pricing rigidities. The timing of the model is such that an unexpected shock to capital quality [inspired by Gertler and Karadi (2011)] might materialize at the start of the period. The pension fund then announces its restoration policy. Afterwards individuals and firms optimize taking into account the capital quality shock and the policy of the pension fund.

\subsection{Demographic Structure}

We consider a unit mass of individuals that is split up in two distinct groups. As in Gertler (1999), individuals have finite lives and flow through two consecutive stages of life: work and retirement. Each individual is born as a worker and conditional on being a worker in the current period, the probability of remaining one in the next period is $\omega$ and the probability of becoming retired in the next period is $1-\omega$. Upon reaching retirement, the probability of surviving until the next period is $\gamma$ and the probability of death is $1-\gamma$. In order to facilitate aggregation within each group, we assume that the probabilities of retirement and death are independent of age. Furthermore, we assume that the number of individuals within each cohort is "large". Denote by $N^{w}$ the stock of workers and by $N^{r}$ the stock of retirees. We focus on the steady state of the demographics in which the stock of workers and retirees is stable. Since each period a share $1-\omega$ of workers retires, we assume that $(1-\omega) N^{w}$ workers are born each period. In order to keep the stock of retirees constant, we need that $N^{r}=(1-\omega) N^{w}+\gamma N^{r}$. This holds when we start out with the (old-age) dependency ratio $\psi=\frac{N^{r}}{N^{w}}=\frac{1-\omega}{1-\gamma}$.

\subsection{Pension Fund}

The fund aims to achieve a certain funding rate (the ratio of its assets to liabilities). If its funding rate is below target, the pension fund faces a deficit and has to restore the balance between its assets and its liabilities. We refer to the specific menu of the announced contribution, accumulation, and revaluation rate as the restoration policy of the pension fund. The other agents in the model will not be able to influence this decision, because the pension fund announces its policy before other agents make their decisions, participation in the pension scheme is mandatory for the retirees and workers, and the number of individuals within each cohort is "large". ${ }^{1}$ We allow for flexibility in pension system design along various dimensions. Depending on the parameterization, we fix the target funding rate, the type of pension fund accounting framework, the recovery speed when the funding rate deviates from the target funding rate, and the instruments used to restore financial adequacy. 
2.2.1. Pension fund accounting. Since the restoration policy of the pension fund is determined at the start of the period, we use beginning-of-period notation for the state variables relevant to the finances of the pension fund (contrary to the end-of-period notation used later in the model for the savings of individuals and the capital stock of the economy).

Pension fund liabilities. At the start of period $t$, the liabilities of the pension fund are given by the present discounted value of the previously accumulated pension wealth of currently alive workers and retirees:

$$
L_{t}^{f}=R_{t}^{r, f} B_{t}^{r}+R_{t}^{w, f} B_{t}^{w}
$$

which is the sum of the size of the accumulated annuity of the group of retirees $B_{t}^{r}$ and workers $B_{t}^{w}$ multiplied by the corresponding annuity factors $R_{t}^{r, f}$ and $R_{t}^{w, f}$. $B_{t}^{r}$ and $B_{t}^{w}$ denote the real number of per-period pension benefits that the group of retirees and workers receive each period in which they are retired. The annuity factors denote the real present discounted value of the expected lifetime payment by the pension fund to a fund participant per unit of accumulated per-period pension benefits. The pension fund liabilities are affected by the capital quality shock through the real interest rate. Note that the revaluation and accrual of pension benefits from period $t$ onwards do not yet belong to the liabilities of the pension fund at the start of the period. This is in accordance with Novy-Marx and Rauh (2011) who recognize the Accumulated Benefit Obligation (ABO) as a proper definition of the liabilities of a pension fund. Even if the pension fund would be completely frozen, the ABO would denote the current value of accrued pension benefits still contractually owed to pension fund participants.

The evolutions of the annuities are given by

$$
\begin{aligned}
\left(\Pi_{t}\right)^{a c c} B_{t}^{r}= & \gamma\left(\mu_{t-1} B_{t-1}^{r}+v_{t-1} \xi w_{t-1} L_{t-1}^{r}\right) \\
& +(1-\omega)\left(\mu_{t-1} B_{t-1}^{w}+v_{t-1} w_{t-1} L_{t-1}^{w}\right) \\
\left(\Pi_{t}\right)^{a c c} B_{t}^{w}= & \omega\left(\mu_{t-1} B_{t-1}^{w}+v_{t-1} w_{t-1} L_{t-1}^{w}\right)
\end{aligned}
$$

where $\Pi_{t}$ denotes the gross inflation from period $t-1$ till $t, \mu_{t}$ is the revaluation instrument, $v_{t}$ the accrual rate on labor income, $\xi \in(0,1]$ the relative productivity of retirees, $w_{t}$ the wage rate, $L_{t}^{r}$ the labor supply of the group of retirees, and $L_{t}^{w}$ the labor supply of the group of workers. Due to the assumption that the number of individuals within each cohort is "large" and since each period a fraction $1-\gamma$ of retirees deceases, $B_{t}^{r}$ contains a $\gamma$ share of the accumulated annuity of the group of retirees at the end of period $t-1$. Additionally, since each period a fraction $1-\omega$ of workers retires, $B_{t}^{r}$ contains a $1-\omega$ share of the accumulated annuity of the group of workers at the end of period $t-1$. The remaining $\omega$ share is contained in $B_{t}^{w}$, while newborn workers in period $t$ start out without any previously accumulated pension wealth. In the real accounting framework, $a c c=0$. In the nominal accounting framework individuals accumulate nominal pension 
wealth and therefore $a c c=1$ to adjust the real value of the annuities $B_{t}^{r}$ and $B_{t}^{w}$ for the change in the price level.

The pension fund annuity factors are given by

$$
\begin{aligned}
& R_{t}^{r, f}=1+\frac{\gamma}{\left(\Pi_{t+1}\right)^{a c c}\left(1+r_{t+1}\right)} R_{t+1}^{r, f}, \\
& R_{t}^{w, f}=\frac{1}{\left(\Pi_{t+1}\right)^{a c c}\left(1+r_{t+1}\right)}\left(\omega R_{t+1}^{w, f}+(1-\omega) R_{t+1}^{r, f}\right) .
\end{aligned}
$$

$R_{t}^{r, f}$ denotes the real present discounted value of the expected lifetime payment by the pension fund to a retiree per unit of accumulated per-period pension benefits (similarly for $R_{t}^{w, f}$ ). The pension fund discounts future pension payments at the real interest rate in the real accounting framework. In the nominal accounting framework, the pension fund instead discounts future pension payments at the nominal interest rate, where we use the Fisher relation $1+i_{t}=\Pi_{t+1}\left(1+r_{t+1}\right)$. We can interpret $R_{t}^{r, f}$ and $R_{t}^{w, f}$ as "no policy" annuity factors, because the pension fund assumes $\mu_{t+i}=1, i=0,1,2, \ldots$ when determining them. This reflects a "normal" course of action in which the pension fund fully covers extended promises to retirees and workers and is in accordance with the definition of the ABO by Novy-Marx and Rauh (2011).

Pension fund assets. The assets of the pension fund are comprised of the paid contributions by workers and retirees, which are invested in the capital stock of the economy. Each period, the pension fund receives the pension contributions $\tau_{t} w_{t} L_{t}$, where $\tau_{t}$ denotes the contribution rate on labor income and $L_{t}$ denotes the aggregate labor supply, and pays out $\mu_{t} B_{t}^{r}$ to the currently retired. The pension fund starts out in period $t-1$ with $A_{t-1}^{f}$ worth of assets and receives a return on its investment in the capital stock of $1+r_{t}$. The pension fund assets are affected by the capital quality shock through the real interest rate. This gives the following recursive formulation for the pension fund capital:

$$
A_{t}^{f}=\left(1+r_{t}\right)\left(A_{t-1}^{f}+\tau_{t-1} w_{t-1} L_{t-1}-\mu_{t-1} B_{t-1}^{r}\right) .
$$

When discussing the pension fund policy in Section 2.2.2 it will be useful to have a recursive definition of the liabilities of the pension fund. We can achieve this by substituting identities (2-5) in equation (1):

$$
\begin{aligned}
L_{t}^{f}=(1 & \left.+r_{t}\right)\left(\mu_{t-1} L_{t-1}^{f}+\left(R_{t-1}^{r, f}-1\right) v_{t-1} \xi w_{t-1} L_{t-1}^{r}\right. \\
& \left.+R_{t-1}^{w, f} v_{t-1} w_{t-1} L_{t-1}^{w}-\mu_{t-1} B_{t-1}^{r}\right),
\end{aligned}
$$

which states that the pension fund liabilities at the start of period $t$ are equal to the current value of the revalued liabilities of the previous period $\mu_{t-1} L_{t-1}^{f}$, plus the real present discounted value of newly issued pension entitlements to retirees $\left(R_{t-1}^{r, f}-1\right) v_{t-1} \xi w_{t-1} L_{t-1}^{r}$ and workers $R_{t-1}^{w, f} v_{t-1} w_{t-1} L_{t-1}^{w}$, minus the fulfilled pension promises to retirees $\mu_{t-1} B_{t-1}^{r}$. 
2.2.2. Pension fund restoration policy. Pension fund regulations generally stipulate that pension funds should attain a target funding rate $\bar{f} r$ in the long term, which is the ratio of the steady-state value of the assets of the pension fund to its liabilities. Additionally, regulations prescribe that any funding surplus or deficit should be reduced over time to ensure that the pension fund does not run out of assets and that participation constraints are not a concern. To replicate such regulations in our model, we suppose that the policy of the pension fund is set to reduce the funding gap of the next period to a fraction $v$ of the current funding gap:

$$
A_{t+1}^{f}-\bar{f} r L_{t+1}^{f}=v\left(A_{t}^{f}-\bar{f} r L_{t}^{f}\right)
$$

where the funding gap is to be closed within one period if $v=0$ and the funding gap is gradually closed over time if $0<v<1$. To get a better picture of how the contribution rate on labor income $(\tau)$, the accumulation rate of pension rights $(\nu)$, and the revaluation of previously accumulated pension wealth $(\mu)$ relate to the closure of the funding gap, we roll over equations (6) and (7) by one period and substitute them into equation (8) to obtain:

$$
\begin{aligned}
& \underbrace{\frac{1+r_{t+1}-v}{1+r_{t+1}}}_{\text {closure fraction }} \underbrace{\left(A_{t}^{f}-\bar{f} r L_{t}^{f}\right)}_{\text {funding gap }}= \\
& \overline{f r}(\underbrace{\frac{1-\bar{f} r}{\bar{f} r} \mu_{t} B_{t}^{r}+\left(\mu_{t}-1\right) L_{t}^{f}}_{\text {revaluation }}+\underbrace{v_{t} w_{t}\left(\left(R_{t}^{r, f}-1\right) \xi_{t} L_{t}^{r}+R_{t}^{w, f} L_{t}^{w}\right)}_{\text {accrual }})-\underbrace{\tau_{t} w_{t} L_{t}}_{\text {contribution }},
\end{aligned}
$$

where the left-hand side denotes the "gap to be filled" and the right-hand side specifies the ways in which the pension fund can do so. For instance, if $A_{t}^{f}<\overline{f r} L_{t}^{f}$ the pension fund can reduce the funding gap by writing down the value of previously accumulated pension rights $\left(\mu_{t}<1\right)$, hiking the contribution rate (increase $\tau_{t}$ ) or lowering the accumulation of new pension benefits (decrease $\left.v_{t}\right){ }^{2}$ Note that when $0<\overline{f r}<1$ a Pay-As-You-Go element is introduced in the funded pension system. Since in the steady state the assets of the pension fund are smaller than its liabilities the pension fund pays out a larger portion of the currently paid contributions directly to retirees. This is reflected in the term $\frac{1-\bar{f} r}{\bar{f} r} \mu_{t} B_{t}^{r}>0$ when $0<\bar{f} r<1$.

2.2.3. Various types of pension systems. The pension fund structure nests a range of different existing pension systems. In the simulations below, we will analyze the following three types of pension systems: Laissez-Faire, DC, and DB. For each system we will discuss what type of restoration policy the pension fund implements when it faces a funding gap. 
- Laissez-Faire (also known as Individual DC): In this pension arrangement there effectively is no pension system; agents save for their own retirement. The pension fund does not levy contributions $\left(\tau_{t}=0, \forall t\right)$, agents do not build up pension benefits $\left(v_{t}=0, \forall t\right)$, and $A_{t}^{f}=L_{t}^{f}=0, \forall t$. This Laissez-Faire system can also be referred to as an individual DC pension system where agents save via a private account. Agents reap a private return on the capital market (contrary to the collective return that would be reaped through the pension fund) and are entirely exposed to any unanticipated changes to the value of their retirement savings. This pension arrangement will serve as a benchmark for the other two types of pension systems.

- DC (also known as Collective DC): In this pension arrangement, the contributions to the pension fund and the accrual of pension benefits are predetermined. The fund thus fixes the contribution rate $\left(\tau_{t}=\bar{\tau}, \forall t\right)$ and accrual rate $\left(v_{t}=\right.$ $\bar{v}, \forall t$ ) on labor income, where $\bar{\tau}$ and $\bar{v}$ denote the steady-state values of the contribution and accrual rate, respectively. The revaluation instrument $\mu$ is used to close the funding gap in accordance with condition (9). Since retirees are most reliant on receiving pension benefits, they will be severely affected in case of an adverse shock to capital quality.

- DB: In this pension arrangement, the fund fixes the revaluation instrument $\mu_{t}=1, \forall t$ and the accrual rate on labor income $v_{t}=\bar{v}, \forall t$ so that it fully covers extended pension promises to fund participants (either in a real or nominal sense, depending on the accounting framework). The contribution rate $\tau$ is used to close any funding gap in accordance with condition (9). When the pension fund guarantees the value of accumulated pension benefits, the retirees are relatively unaffected by an adverse capital quality shock. On the other hand, workers are made responsible for the closure of the funding gap through an increase in contribution payments, forcing them to contribute more than what they are expected to receive in return. Since the pension fund contributions are levied as a fraction of labor income, the DB pension fund distorts labor supply decisions and therefore has substantial consequences for other macroeconomic variables such as output.

The pension systems described above are extreme cases: either there is effectively no pension fund, or if there is a pension fund, the funding gap is closed using one instrument exclusively. Romp (2013) shows that it is possible to add weighting factors to equation (9) to create a hybrid system that is a convex combination of the two extremes. However, any such convex combination will give impulse responses that lie between the extreme cases of DC and DB. To highlight the macroeconomic effects of various types of pension fund restoration policy we elect to focus on these extreme cases.

\subsection{Decision Problems of Workers and Retirees}

Individuals face two types of idiosyncratic risk throughout their life cycle. Firstly, workers might become retired in the next period, which constitutes an income 
loss due to the assumed lower productivity of retirees. Secondly, retirees face the uncertainty about their time of death. Similar to Blanchard (1985), we introduce annuity markets that shelter retirees from the risk of the timing of death. Upon retirement, individuals hand over their private savings to a perfectly competitive mutual fund that invests the proceeds in the market and promises a return $\frac{1+r}{\gamma}$ only to those who survive until the next period. Since the return of the mutual fund dominates the return of the market, all retiring individuals decide to hand over their private savings. Additionally, the existence of the mutual fund ensures that there are no accidental bequests that need to be distributed over the surviving individuals. While it is possible to introduce an insurance market that mitigates the risk of income loss as a result of retirement, doing so would allow individuals to smooth their labor income over their life cycle and in turn would kill the lifecycle structure that we aim to impose. Instead, we specify that individuals are risk neutral with respect to income risk. Since the income risk in this model follows from the mechanical assumption of a constant transition probability into retirement, individuals have risk neutral preferences so as to decrease the impact of income variation in the model.

Let $V^{z}\left(a_{t-1}^{z}, b_{t}^{z}\right)$ be the value function of a particular individual at period $t$, where $z=\{r, w\}$ indicates whether the individual is a retiree $(r)$ or a worker $(w)$ in that period, $a_{t-1}^{z}$ denotes the number of consumption goods saved, and $b_{t}^{z}$ denotes the accumulated pension annuity at the start of period $t .^{3}$ Preferences of retirees and workers are of the RINCE type and given by

$$
\begin{aligned}
& \left(\left[\left(c_{t}^{r}\right)^{v}\left(1-l_{t}^{r}\right)^{1-v}\right]^{\rho}+\gamma \beta\left[V^{r}\left(a_{t}^{r}, b_{t+1}^{r}\right)\right]^{\rho}\right)^{\frac{1}{\rho}} \\
& \left(\left[\left(c_{t}^{w}\right)^{v}\left(1-l_{t}^{w}\right)^{1-v}\right]^{\rho}+\beta\left[\omega V^{w}\left(a_{t}^{w}, b_{t+1}^{w}\right)+(1-\omega) V^{r}\left(a_{t}^{w}, b_{t+1}^{w}\right)\right]^{\rho}\right)^{\frac{1}{\rho}},
\end{aligned}
$$

where $c_{t}^{z}$ and $l_{t}^{z}$ denote consumption and labor supply, respectively. ${ }^{4}$ Each individual has one unit of time and enjoys $1-l_{t}^{z}$ units of leisure. The curvature parameter $\rho$ implies that individuals have a desire to smooth consumption over time. As shown by Farmer (1990), $\sigma=\frac{1}{1-\rho}$ is the familiar intertemporal elasticity of substitution. The RINCE preferences restrict individuals to be risk neutral with respect to income risk, but allow them to have any arbitrary intertemporal elasticity of substitution. Since we motivate the presence of income risk on the mechanical grounds of generating meaningful lifecycle behavior, it is favorable that this class of preferences allows for meaningful preferences with respect to smoothing income over time. Additionally, the specification of RINCE preferences allows us to aggregate the behavior of workers and retirees. ${ }^{5}$

2.3.1. Retiree decision problem. A retiree, who is indexed by $i$, maximizes the following objective in period $t$ :

$$
V^{r, i}\left(a_{t-1}^{r, i}, b_{t}^{r, i}\right)=\max _{c_{t}^{r, i}, l_{t}^{r, i}, a_{t}^{r, i}, b_{t+1}^{r, i}}\left(\left[\left(c_{t}^{r, i}\right)^{v}\left(1-l_{t}^{r, i}\right)^{1-v}\right]^{\rho}+\gamma \beta\left[V^{r, i}\left(a_{t}^{r, i}, b_{t+1}^{r, i}\right)\right]^{\rho}\right)^{\frac{1}{\rho}},
$$


subject to:

$$
\begin{aligned}
a_{t}^{r, i} & =\frac{1+r_{t}}{\gamma} a_{t-1}^{r, i}+\left(1-\tau_{t}\right) \xi w_{t} l_{t}^{r, i}+\mu_{t} b_{t}^{r, i}-c_{t}^{r, i}, \\
b_{t+1}^{r, i} & =\frac{\mu_{t} b_{t}^{r, i}+v_{t} \xi w_{t} l_{t}^{r, i}}{\left(\Pi_{t+1}\right)^{a c c}},
\end{aligned}
$$

where $a_{t}^{r, i}$ are the private savings of the retiree at period $t$, yielding a return of $\frac{1+r_{t+1}}{\gamma}$ in period $t+1$ through the mutual fund, and $r_{t}$ is the real interest rate on savings from period $t-1$ till period $t$. The private financial wealth of the retiree is given by $\frac{1+r_{t}}{\gamma} a_{t-1}^{r, i}$ and $b_{t}^{r, i}$ is the size of the retiree annuity. The effective wage rate of the retiree is given by $\xi w_{t}$. When working the retiree pays a mandatory contribution to the pension fund equal to a share $\tau_{t}$ of labor income. In return his annuity $b_{t+1}^{r, i}$ increases by a share $v_{t}$ of labor income. The retiree receives his previously accumulated annuity $\mu_{t} b_{t}^{r, i}$ from the pension fund, which is corrected for the revaluation instrument $\mu_{t}$ (and the inflation $\Pi_{t}$ in the nominal pension fund accounting framework). The retiree, when deciding on his optimal amount of labor to supply and goods to consume, takes as given the financial position of the pension fund and thus the future path of its policy. ${ }^{6}$

Supplementary Appendices A.1.1 and A.1.2 show that the decision problem of the retiree gives rise to the following two conditions:

$$
\begin{aligned}
c_{t+1}^{r, i} & =\left(\beta\left(1+r_{t+1}\right)\left(\frac{\left(1-\tau_{t}^{r}\right) w_{t}}{\left(1-\tau_{t+1}^{r}\right) w_{t+1}}\right)^{(1-v) \rho}\right)^{\sigma} c_{t}^{r, i}, \\
1-l_{t}^{r, i} & =\frac{1-v}{v} \frac{c_{t}^{r, i}}{\left(1-\tau_{t}^{r}\right) \xi w_{t}},
\end{aligned}
$$

where equation (10) is the retiree Euler equation and equation (11) the optimal labor supply decision. The term $\tau_{t}^{r}=\tau_{t}-\left(R_{t}^{r}-1\right) v_{t}$ is the effective labor income contribution rate that the retiree faces, where $R_{t}^{r}$ is the retiree annuity factor which denotes the expected real present discounted value to a retiree of receiving a consumption good each period until death, corrected for revaluation (and inflation in the nominal accounting framework). Depending on the pension fund restoration policy the effective contribution rate $\tau^{r}$ acts as either an effective tax $\left(\tau^{r}>0\right)$ or subsidy $\left(\tau^{r}<0\right)$ on labor income. We define the retiree annuity factor as

$$
R_{t}^{r}=1+\mu_{t+1} \frac{\gamma}{\left(\Pi_{t+1}\right)^{a c c}\left(1+r_{t+1}\right)} R_{t+1}^{r} .
$$

The retiree annuity factor differs from $R_{t}^{r, f}$ due to the inclusion of the future path of the revaluation instrument $\mu$ (which was omitted from $R_{t}^{r, f}$ for supervision purposes). Whereas $R_{t}^{r . f}$ is to be interpreted as a "no policy" annuity factor used by the pension fund to determine the restoration policy of the current period, the retiree takes into account the future path of the pension fund restoration policy when determining how much labor to supply and how much to consume. 
Let $\Delta_{t}^{r}$ denote the inverse of the MPCW of a retiree and let $x_{t}^{r, i} \equiv c_{t}^{r, i}+(1-$ $\left.\tau_{t}^{r}\right) \xi w_{t}\left(1-l_{t}^{r, i}\right)=\frac{c_{t}^{r, i}}{v}$ denote retiree full consumption. Additionally, let retiree full income $d_{t}^{r, i}$ and retiree human wealth $h_{t}^{r, i}$ be defined as

$$
\begin{aligned}
& d_{t}^{r, i}=\left(1-\tau_{t}^{r}\right) \xi w_{t}, \\
& h_{t}^{r, i}=d_{t}^{r, i}+\frac{\gamma}{1+r_{t+1}} h_{t+1}^{r, i} .
\end{aligned}
$$

Supplementary Appendix A.1.3 shows that full consumption and the inverse MPCW out of wealth of a retiree satisfy the following two conditions:

$$
\begin{aligned}
& x_{t}^{r, i}=\frac{1}{\Delta_{t}^{r}}\left(\frac{1+r_{t}}{\gamma} a_{t-1}^{r, i}+h_{t}^{r, i}+\mu_{t} b_{t}^{r, i} R_{t}^{r}\right), \\
& \Delta_{t}^{r}=1+\gamma \beta^{\sigma} \Delta_{t+1}^{r}\left(\left(1+r_{t+1}\right)\left(\frac{\left(1-\tau_{t}^{r}\right) w_{t}}{\left(1-\tau_{t+1}^{r}\right) w_{t+1}}\right)^{1-v}\right)^{\sigma-1} .
\end{aligned}
$$

Retirees spend a fraction $\frac{1}{\Delta_{t}^{r}}$ of their total lifetime wealth on consumption goods and leisure. Retiree total lifetime wealth consists of the sum of private financial wealth $\frac{1+r_{t}}{\gamma} a_{t-1}^{r, i}$, human wealth $h_{t}^{r, i}$ (which contains the expected value of pension wealth to be accumulated in the future), and previously accumulated pension wealth $\mu_{t} b_{t}^{r, i} R_{t}^{r}$. Since the inverse MPCW of a retiree is the same for all retirees, irrespective of age and total lifetime wealth, aggregation over retirees will be straightforward. Supplementary Appendix A.1.3 shows that equations (14) and (15) can be used to derive an analytical expression for the indirect retiree value function:

$$
V_{t}^{r, i}=\left(\Delta_{t}^{r}\right)^{\frac{1}{\rho}} v x_{t}^{r, i}\left(\frac{1-v}{v} \frac{1}{\left(1-\tau_{t}^{r}\right) \xi w_{t}}\right)^{1-v}
$$

2.3.2. Worker decision problem. A worker, who is indexed by $j$, maximizes the following objective in period $t$ :

$$
\begin{gathered}
V^{w, j}\left(a_{t-1}^{w, j}, b_{t}^{w, j}\right)=\max _{c_{t}^{w, j}, l_{t}^{w, j}, a_{t}^{w, j}, b_{t+1}^{w, j}}\left(\left[\left(c_{t}^{w, j}\right)^{v}\left(1-l_{t}^{w, j}\right)^{1-v}\right]^{\rho}+\beta\left[\omega V^{w, j}\left(a_{t}^{w, j}, b_{t+1}^{w, j}\right)\right.\right. \\
\left.\left.+(1-\omega) V^{r, j}\left(a_{t}^{w, j}, b_{t+1}^{w, j}\right)\right]^{\rho}\right)^{\frac{1}{\rho}},
\end{gathered}
$$

subject to:

$$
\begin{aligned}
a_{t}^{w, j} & =\left(1+r_{t}\right) a_{t-1}^{w, j}+\left(1-\tau_{t}\right) w_{t} l_{t}^{w, j}+f_{t}^{w, j}-c_{t}^{w, j}, \\
b_{t+1}^{w, j} & =\frac{\mu_{t} b_{t}^{w, j}+v_{t} w_{t} l_{t}^{w, j}}{\left(\Pi_{t+1}\right)^{a c c}},
\end{aligned}
$$

where $a_{t}^{w, j}$ are the private savings of the worker at the end of period $t$ and $b_{t+1}^{w, j}$ is the size of the worker annuity at the start of period $t+1$. The private financial wealth of the worker is given by $\left(1+r_{t}\right) a_{t-1}^{w, j}$ and the worker receives profits 
$f_{t}^{w, j}$ from the intermediate and capital good producing firms. Supplementary Appendices A.2.1 and A.2.2 show that the decision problem of the worker gives rise to the following two conditions:

$$
\begin{gathered}
\omega c_{t+1}^{w, j}+(1-\omega) c_{t+1}^{r, j}\left(\frac{1-\tau_{t+1}^{w}}{1-\tau_{t+1}^{r}} \frac{1}{\xi}\right)^{1-v}\left(\frac{\Delta_{t+1}^{w}}{\Delta_{t+1}^{r}}\right)^{\frac{\sigma}{1-\sigma}}= \\
\left(\beta\left(1+r_{t+1}\right) \Omega_{t+1}\left(\frac{\left(1-\tau_{t}^{w}\right) w_{t}}{\left(1-\tau_{t+1}^{w}\right) w_{t+1}}\right)^{(1-v) \rho}\right)^{\sigma} c_{t}^{w, j}, \\
1-l_{t}^{w, j}=\frac{1-v}{v} \frac{c_{t}^{w, j}}{\left(1-\tau_{t}^{w}\right) w_{t}},
\end{gathered}
$$

where we define:

$$
\Omega_{t}=\omega+(1-\omega)\left(\frac{1-\tau_{t}^{w}}{1-\tau_{t}^{r}} \frac{1}{\xi}\right)^{1-v}\left(\frac{\Delta_{t}^{w}}{\Delta_{t}^{r}}\right)^{\frac{1}{1-\sigma}} .
$$

The worker Euler equation (16) shows that the worker takes into account that he might become retired in period $t+1$. The term $\Omega_{t}$ reflects that a worker, when switching into retirement, reaches the next (and irreversible) stage in his life cycle. The retirement stage is characterized by a different effective wage rate (captured by $\xi$ ), MPCW (captured by $\Delta_{t}^{w}$ and $\Delta_{t}^{r}$ ), and effective pension fund contribution rate on labor income (captured by $\tau^{r}$ and $\tau^{w}$ ). The effective worker contribution rate is given by $\tau_{t}^{w}=\tau_{t}-R_{t}^{w} v_{t}$ and, similarly to the retiree effective contribution rate, reflects the balance between the costs $\left(\tau_{t}\right)$ and the benefits $\left(R_{t}^{w} v_{t}\right)$ of the mandatory pension fund participation to the worker. We define the worker annuity factor as:

$$
R_{t}^{w}=\frac{\mu_{t+1}}{\left(\Pi_{t+1}\right)^{a c c}\left(1+r_{t+1}\right)}\left(\frac{\omega}{\Omega_{t+1}} R_{t+1}^{w}+\left(1-\frac{\omega}{\Omega_{t+1}}\right) R_{t+1}^{r}\right) .
$$

The worker annuity factor denotes the expected real present discounted value to a worker of receiving one consumption good each period when retired until death, corrected for revaluation (and inflation in the nominal accounting framework). The definition of $R_{t}^{w}$ shows that the term $\Omega_{t}$ can be interpreted as a subjective reweighting of transition probabilities. The irreversible event of transitioning into retirement entails an income shock for the individual and implies that the worker attaches more importance to receiving income when retired compared to remaining a worker in future periods. This is reflected by the fact that the worker attaches a subjective transition probability of $\frac{\omega}{\Omega_{t+1}}$ (compared to the objective probability $\omega)$ to income received when remaining a worker in period $t+1$ and a subjective transition probability of $1-\frac{\omega}{\Omega_{t+1}}$ (compared to the objective probability $1-\omega$ ) when becoming a retiree in period $t+1 .{ }^{7}$ The worker annuity factor $R_{t}^{w}$ thus does not only differ from $R_{t}^{w, f}$ due to the inclusion of the future path of the revaluation instrument $\mu$, but also due to the subjective reweighting of transition probabilities 
of the worker. The pension fund is an ongoing concern, which does not have a lifecycle motive like workers do, and uses the objective transition probabilities for the calculation of the annuity factor $R_{t}^{w, f}$.

Gertler (1999) shows that the subjective reweighting of transition probabilities causes the Ricardian equivalence to break down in this type of model. The path of government debt influences macroeconomic outcomes and therefore the pension fund is also non-Ricardian. The pension fund also influences macroeconomic outcomes by introducing a new asset in the economy. When workers invest private financial wealth in the capital stock of the economy they obtain the same return regardless of their lifecycle stage in the next period. In the absence of the pension fund, workers thus cannot invest in an asset that yields a return conditional on whether they are a retiree or a worker in the next period. The pension fund introduces such an asset: it only pays out the accumulated pension benefits when the worker is retired and the mandatory investment in the pension fund thus yields a return that is conditioned on the specific lifecycle stage of the individual. Workers cannot replicate this when they invest private financial wealth in the capital stock.

Let $\Delta_{t}^{w}$ denote the inverse of the MPCW of a worker and let $x_{t}^{w, j} \equiv c_{t}^{w, j}+(1-$ $\left.\tau_{t}^{w}\right) w_{t}\left(1-l_{t}^{w, j}\right)=\frac{c_{t}^{w, j}}{v}$ denote worker full consumption. Additionally, let worker full income $d_{t}^{w, j}$ and worker human wealth $h_{t}^{w, j}$ be defined as:

$$
\begin{aligned}
& d_{t}^{w, j}=\left(1-\tau_{t}^{w}\right) w_{t}+f_{t}^{w, j} \\
& h_{t}^{w, j}=d_{t}^{w, j}+\frac{1}{1+r_{t+1}}\left(\frac{\omega}{\Omega_{t+1}} h_{t+1}^{w, j}+\left(1-\frac{\omega}{\Omega_{t+1}}\right) h_{t+1}^{r, j}\right) .
\end{aligned}
$$

Supplementary Appendices A.2.2 and A.2.3 show that the full consumption function and inverse MPCW of a worker satisfy the following two conditions:

$$
\begin{aligned}
& x_{t}^{w, j}=\frac{1}{\Delta_{t}^{w}}\left(\left(1+r_{t}\right) a_{t-1}^{w, j}+h_{t}^{w, j}+\mu_{t} b_{t}^{w, j} R_{t}^{w}\right) \\
& \Delta_{t}^{w}=1+\beta^{\sigma} \Delta_{t+1}^{w}\left(\left(1+r_{t+1}\right) \Omega_{t+1}\left(\frac{\left(1-\tau_{t}^{w}\right) w_{t}}{\left(1-\tau_{t+1}^{w}\right) w_{t+1}}\right)^{1-v}\right)^{\sigma-1} .
\end{aligned}
$$

Workers spend a fraction $\frac{1}{\Delta_{t}^{W}}$ of their total lifetime wealth on consumption goods and leisure. Worker total lifetime wealth is comprised of the sum of private financial wealth $\left(1+r_{t}\right) a_{t-1}^{w, j}$, human wealth $h_{t}^{w, j}$ (which contains the expected value of pension wealth to be accumulated in the future), and previously accumulated pension wealth $\mu_{t} b_{t}^{w, j} R_{t}^{w}$. Since the inverse MPCW of a worker is the same for all workers, irrespective of age and total lifetime wealth, aggregation over workers will be straightforward. Supplementary Appendices A.2.2 and A.2.3 show that equations (21) and (22) can be used to derive an analytical expression for the indirect worker value function:

$$
V_{t}^{w, j}=\left(\Delta_{t}^{w}\right)^{\frac{1}{\rho}} v x_{t}^{w, j}\left(\frac{1-v}{v} \frac{1}{\left(1-\tau_{t}^{w}\right) w_{t}}\right)^{1-v} \text {. }
$$


2.3.3. Aggregation over retirees and workers. Aggregate variables are identified by the lack of a superscript $i$ and $j$ and are written in capital letters. We start by aggregating human wealth and private financial wealth and afterwards aggregate the consumption and labor supply functions. Recall that the aggregate annuities of the retirees $B_{t}^{r}$ and workers $B_{t}^{w}$ are defined recursively by conditions (2) and (3). Aggregate full income of retirees and workers satisfies:

$$
\begin{aligned}
D_{t}^{r} & =N^{r}\left(1-\tau_{t}^{r}\right) \xi w_{t}, \\
D_{t}^{w} & =N^{w}\left(1-\tau_{t}^{w}\right) w_{t}+F_{t},
\end{aligned}
$$

where $F_{t}$ denotes the aggregate profits of the intermediate and capital good producers and is specified by condition (B.14) in Supplementary Appendix B.6. Note that we do not have to specify how firm profits are distributed over individual workers due to the structure of the derived worker consumption function. Aggregate human wealth of retirees and workers satisfies:

$$
\begin{aligned}
H_{t}^{r} & =D_{t}^{r}+\frac{\gamma}{1+r_{t+1}} H_{t+1}^{r} \\
H_{t}^{w} & =D_{t}^{w}+\frac{1}{1+r_{t+1}}\left(\frac{\omega}{\Omega_{t+1}} H_{t+1}^{w}+\left(1-\frac{\omega}{\Omega_{t+1}}\right) \frac{1}{\psi} H_{t+1}^{r}\right) .
\end{aligned}
$$

Aggregate private savings of retirees and workers can be defined recursively:

$$
\begin{aligned}
& A_{t}^{r}=\left(1+r_{t}\right) A_{t-1}^{r}+\mu_{t} B_{t}^{r}+\left(1-\tau_{t}\right) \xi w_{t} L_{t}^{r}-C_{t}^{r}+\frac{1-\omega}{\omega} A_{t}^{w}, \\
& A_{t}^{w}=\omega\left(\left(1+r_{t}\right) A_{t-1}^{w}+\left(1-\tau_{t}\right) w_{t} L_{t}^{w}+F_{t}-C_{t}^{w}\right) .
\end{aligned}
$$

Condition (23) shows that the aggregate private savings of the retired in period $t+$ 1 consists of two parts. Firstly, it consists of the sum of income that was not spent by retirees in period $t$. The lack of a multiplication by $\gamma$ reflects that all savings by retirees in period $t$ are transferred to the surviving retirees in period $t+1$. On the level of the group of retirees, private financial wealth invested in the capital stock of the economy yields a return of $1+r_{t}$. Secondly, it consists of the sum of income not spent in period $t$ by those workers who become retired in period $t+1$. The remainder of the sum of income not spent in period $t$ by workers is given by equation (24), since newly born workers start out without private savings. Having specified retiree and worker private savings, human wealth, and pension wealth, we arrive at the aggregate full consumption functions:

$$
X_{t}^{z}=\frac{1}{\Delta_{t}^{z}}\left(\left(1+r_{t}\right) A_{t-1}^{z}+H_{t}^{z}+\mu_{t} B_{t}^{z} R_{t}^{z}\right), \quad z \in\{w, r\} .
$$

Aggregate consumption of retirees, workers, and total population satisfies:

$$
\begin{aligned}
C_{t}^{z} & =v X_{t}^{z}, \quad z \in\{w, r\}, \\
C_{t} & =C_{t}^{r}+C_{t}^{w} .
\end{aligned}
$$


Aggregate labor supply of retirees, workers, and total population satisfies, where $w_{t}^{r}=\xi w_{t}$ and $w_{t}^{w}=w_{t}$ :

$$
\begin{aligned}
L_{t}^{z} & =N^{z}-\frac{(1-v) X_{t}^{z}}{\left(1-\tau_{t}^{w}\right) w_{t}^{z}}, \quad z \in\{w, r\}, \\
L_{t} & =L_{t}^{w}+\xi L_{t}^{r} .
\end{aligned}
$$

Aggregate welfare of retirees and workers satisfies:

$$
V_{t}^{z}=\left(\Delta_{t}^{z}\right)^{\frac{1}{\rho}} v X_{t}^{z}\left(\frac{1-v}{v} \frac{1}{\left(1-\tau_{t}^{z}\right) w_{t}^{z}}\right)^{1-v}, \quad z \in\{w, r\} .
$$

\subsection{Firms and Government}

The supply side of the economy is modeled in a familiar New-Keynesian fashion. Intermediate good producing firms borrow from the households and the pension fund to purchase the capital necessary for production. The revenue generated from the sale of the output to retail firms and of the capital after it has been used is spent on the wages of households and used to pay back the loans from households and the pension fund. Capital producing firms buy the used capital and transform it, together with goods purchased from final good producing firms, into new capital. This new capital is sold to intermediate good producing firms who will use it for production in the next period. While intermediate good producing firms do not face investment adjustment costs at the firm level, the capital producing sector is subject to investment adjustment costs à la Fernández-Villaverde and Rubio-Ramírez (2006) and Christiano et al. (2005). The retail firms repackage the purchased output from intermediate good producing firms in order to produce a unique and differentiated retail product. The output of retail firms is sold to final good producing firms, but at a markup due to the differentiated nature of the retail product. In effect, each retail firm has "local" monopoly power. Retail firms face Calvo (1983)-type pricing frictions. The final good producers convert the output of retail firms into final goods, which are then sold to households and capital producers. This splits up the economy in four production sectors. The capital producing sector isolates the investment adjustment costs. The retail goods sector isolates the Calvo pricing and imperfect competition. The intermediate goods sector isolates the pricing of capital and labor. The final goods sector aggregates. There are no government purchases and the central bank sets its monetary policy according to a Taylor rule. Since the decision-making of firms and government is standard in the New-Keynesian literature, we delegate the derivations to Supplementary Appendix B.

\section{MODEL ANALYSIS}

We calibrate the model in Section 3.1, assess the macroeconomic effects of an unexpected adverse capital quality shock that urges the pension fund to close a funding gap in Section 3.2, and consider the welfare implications in Section 3.3. 
TABLE 1. Model parameters (excluding those of the pension fund)

Demographics

Retirement probability of workers

Death probability of retirees

$\begin{array}{ll}1-\omega & \frac{1}{180} \\ 1-\gamma & \frac{1}{60}\end{array}$

Households

Intertemporal elasticity of substitution

Discount factor

Consumption preference

Relative productivity of retirees

Intermediate good producing firms

Cobb-Douglas share of capital

Depreciation rate of capital

AR(1)-coefficient of capital quality shock

$\begin{array}{cc}\sigma & \frac{1}{3} \\ \beta & 1.07^{-\frac{1}{4}} \\ v & 0.6 \\ \xi & 0.2\end{array}$

Capital good producing firms

Investment adjustment costs parameter

1.728

Retail good producing firms

Elasticity of demand for intermediate goods

$\epsilon$

Central bank

Inertial parameter in Taylor rule

$\begin{array}{cc}\eta_{i} & 0 \\ \gamma_{\pi} & 1.5 \\ \gamma_{y} & \frac{1}{8} \\ \bar{\Pi} & 1.0025\end{array}$

\subsection{Baseline Calibration}

Since the restoration policy of a pension fund is a relatively short-term phenomenon, we calibrate the model at a quarterly frequency. Table 1 summarizes the chosen values for each model parameter. The demographic parameters are set such that the implied average working period is 45 years and the average retirement period is 15 years. This is consistent with agents entering the labor force at the age of 20 , working until 65 , and passing away at 80 . The old-age dependency ratio $\frac{1-\omega}{1-\gamma}$ is therefore equal to $\frac{1}{3}$. These values are close to empirical estimates for the euro area in 2008 reported in the statistical annex of the 2009 Ageing Report by the European Commission, who report a life expectancy at birth of 79.5 years and an old-age dependency ratio of 0.27 . The intertemporal elasticity of substitution is a crucial parameter in our analysis. In Gertler (1999)-type models the chosen values range from $\frac{1}{4}$ to $\frac{1}{2}$. In the baseline calibration we set it to the intermediate $\frac{1}{3}$ (implying that $\rho=-2$ ), but we perform sensitivity analyses later in Supplementary Appendix D. The relative productivity of retirees $\xi$ is set to a smaller value than in other papers in this literature to ensure that retiree labor force participation remains low. We set the discount factor $\beta$ to achieve a 
TABLE 2. Pension fund parameters and implied pension fund size in steady state

$\begin{array}{cc}\text { Real } & \begin{array}{c}\text { Nominal } \\ \text { accounting }\end{array} \\ \text { framework } & \text { framework }\end{array}$

\section{Set parameters}

\begin{tabular}{lccc} 
Accrual rate & $v$ & $0.13 \%$ & $0.19 \%$ \\
Steady-state funding rate & $f r$ & $78.27 \%$ & $100 \%$ \\
Funding gap closure speed & $v$ & 0.8409 & 0.8409 \\
Implied steady-state values & & & \\
Contribution rate & $\tau$ & $4.14 \%$ & $3.56 \%$ \\
Pension fund assets to yearly output ratio & $\frac{A^{f}}{4 Y}$ & $88 \%$ & $88 \%$ \\
Contributions to output ratio & $\frac{\tau w L}{Y}$ & $2.10 \%$ & $1.81 \%$ \\
Benefits to output ratio & $\frac{B^{r}}{Y}$ & $3.96 \%$ & $3.49 \%$ \\
Pension fund capital to aggregate capital ratio & $\frac{A^{f}}{K}$ & $40.78 \%$ & $40.04 \%$ \\
Fraction of pension wealth owned by retirees & $\frac{R^{r, f} B^{r}}{L^{f}}$ & $40.13 \%$ & $32.26 \%$ \\
\hline
\end{tabular}

${ }^{\mathrm{a}}$ Targeted value.

yearly real interest rate of roughly $2 \%$ in the steady state. As we implement the capital quality shock of Gertler and Karadi (2011), we calibrate the production sectors and central bank in precisely the same fashion. However, we deviate by setting $\bar{\Pi}=1.0025$ which implies a yearly steady-state net inflation rate of $1 \%$. This gives a meaningful difference between the real and nominal pension fund accounting framework in the steady state.

While the OECD (2017) Pension Markets in Focus report highlights that pension funds have been gaining importance (with pension fund assets growing faster than GDP in most countries from 2006 to 2016), there is still a wide disparity between countries in terms of the size of the pension fund market. For instance, pension fund assets in Denmark, The Netherlands, Canada, and Iceland are larger than $150 \%$ of GDP, while pension fund assets in Spain, Portugal, Norway, France, Italy, and Germany are smaller than $15 \%$ of GDP. In our baseline calibration, we set the pension fund parameters such that the assets of the pension fund are roughly equal to $88 \%$ of yearly output, which is in between the average of $50 \%$ and weighted average of $125 \%$ of OECD countries in 2016 as reported by the Pension Markets in Focus report. We perform sensitivity analyses with respect to the size of the pension fund later in Supplementary Appendix D. Table 2 summarizes the pension fund parameters and several implied indicators of pension fund size in the steady state. In the steady state we postulate that the pension fund covers its extended promises to retirees by setting the revaluation $\mu=1$. Fixing the accrual rate $v$ then determines the size of the balance sheet of the pension fund and implies a steady-state contribution rate $\tau$. We specify that in the steady state the pension fund should achieve a nominal funding rate of $100 \%$. Together 
with a yearly net inflation rate of $1 \%$ in the steady state this implies a real target funding rate of $78.27 \%$ in the real accounting framework. The resulting contributions to output ratios of roughly $2 \%$ are smaller than the OECD average in 2016 of $2.11 \%$ and weighted average of $4.15 \%$, while the benefits to output ratios of roughly $3.5 \%$ and $4 \%$ lie between the OECD average in 2016 of $1.67 \%$ and weighted average of $5.30 \% .^{8}$ The closure speed $v$ is set such that the half-life of the funding gap is equal to 1 year, but we perform sensitivity analyses later in Supplementary Appendix D.

The emerging pension fund system has relatively high benefits to output ratios compared to the contributions to output ratios for two reasons. First, in our model the only investment opportunity for the pension fund is the capital stock, which yields a return akin to an equity investment. In reality, in 2016 pension funds in OECD countries invested roughly $40 \%$ of contributions in bonds according to the Pension Markets in Focus report. The same report states that because of this investment portfolio the geometric average annual real returns of pension funds in OECD countries from 2006 to 2016 were 1.7\%, while the steady-state annual real interest rates are roughly $2.0 \%$. Second, condition (9) shows that underfunded pension funds (where assets are smaller than liabilities) contain a Pay-As-You-Go component. The more underfunded the pension fund, the more contributions are directly transferred to retirees instead of invested. In the wake of the financial crisis of 2008, many pension funds faced funding deficits, explaining the empirically observed low benefits to output ratios relative to the contributions to output ratios.

Table 3 provides an overview of the steady-state values of important endogenous variables. The MPCW is considerably higher for retirees than for workers, which is in line with the calibrations of Gertler (1999)-type models and the empirical estimations by Harrison et al. (2002). The subjective reweighting of transition probabilities $\Omega>1$ drives a substantial wedge between the worker annuity factor $R^{w}$ and the annuity factor applied by the pension fund $R^{w, f}$. Because saving through the pension fund allows workers to condition their future return on their future lifecycle stage, the effective contribution rate of workers $\tau^{w}$ is negative or close to zero. Especially the effective contribution rate of retirees $\tau^{r}$ is negative, which is a feature of uniform policy pension systems in which contribution and accrual rates are equal for all participants irrespective of the participant's age at the payment time of the contribution. Chen and van Wijnbergen (2017) document that this is the case in many public sector pension plans in OECD countries. In the model, workers face the same contribution and accrual rate as retirees despite the fact that the contributions of the workers are expected to be invested for a longer period of time. As a consequence of the sizeable effective subsidy on labor income, the labor force participation of retirees is higher compared to the findings of other papers in this literature and OECD data. ${ }^{9}$

\subsection{Restoring Pension Funding Adequacy after an Adverse Capital Quality Shock}

In this section we describe the restoration policy implemented by DC and DB pension funds and the implications this policy has for the rest of the economy 
TABLE 3. Steady-state values of selected endogenous variables

\begin{tabular}{lccc}
\hline & & $\begin{array}{c}\text { Real } \\
\text { accounting } \\
\text { framework }\end{array}$ & $\begin{array}{c}\text { Nominal } \\
\text { accounting } \\
\text { framework }\end{array}$ \\
\hline Inverse MPCW of workers & $\Delta^{w}$ & 56.87 & 57.91 \\
Inverse MPCW of retirees & $\Delta^{r}$ & 39.02 & 39.57 \\
Yearly real interest rate & $(1+r)^{4}-1$ & $2.13 \%$ & $1.91 \%$ \\
Subjective reweighting of transition & $\Omega$ & 1.01 & 1.01 \\
$\quad$ probabilities & $R^{w}$ & 35.51 & 30.18 \\
Worker annuity factor & $R^{w, f}$ & 23.45 & 18.27 \\
Worker annuity factor of pension fund & $\tau^{w}$ & $-0.48 \%$ & $-2.21 \%$ \\
Effective contribution rate of workers & $\tau^{r}$ & $-1.69 \%$ & $-4.19 \%$ \\
Effective contribution rate of retirees & $\frac{L^{w}}{N^{w}}$ & 0.51 & 0.52 \\
Labor force participation rate of workers & $\frac{L^{r}}{N^{r}}$ & 0.19 & 0.22 \\
Labor force participation rate of retirees & $\frac{K}{Y}$ & 8.62 & 8.79 \\
Capital to output ratio & $\frac{C^{w}}{Y}$ & 0.72 & 0.71 \\
Worker consumption to output ratio & $\frac{C^{r}}{Y}$ & 0.08 & 0.08 \\
Retiree consumption to output ratio & $\frac{I}{Y}$ & 0.20 & 0.21 \\
Investment to output ratio & & & \\
\hline
\end{tabular}

after an unexpected adverse capital quality shock materializes. With the adverse shock to capital quality we aim to replicate the dynamics of a financial crisis such as the one of 2008, but with a specific interest in the financial situation of pension funds. We consider an adverse shock of $1 \%$ to capital quality. ${ }^{10}$

3.2.1. Real pension fund accounting framework. Figure 1 provides a plot of pension fund accounting variables and the implemented restoration policy for the real accounting framework. The unexpected adverse capital quality shock depresses the value of the pension fund assets by roughly $2 \%$ on impact. Despite the fact that the pension fund issues real promises to participants in a DB system, the value of its liabilities is depressed by roughly $1 \%$ on impact due to the response of the real interest rate. Both types of pension funds face a funding deficit of roughly $1 \%$ as a result of the adverse capital quality shock. The DB pension fund responds by significantly increasing the contribution rate on labor income, while the DC pension fund gradually writes down the value of previously accumulated pension wealth. In the DB pension system retirees are comparatively well off since the value of their pension wealth is guaranteed. However, the workers are comparatively worse off as they rely on their labor income. This is reflected in the plots of the effective contribution rates of workers and retirees. Figure 1 highlights that the effective contribution rate of workers turns positive, while the effective 

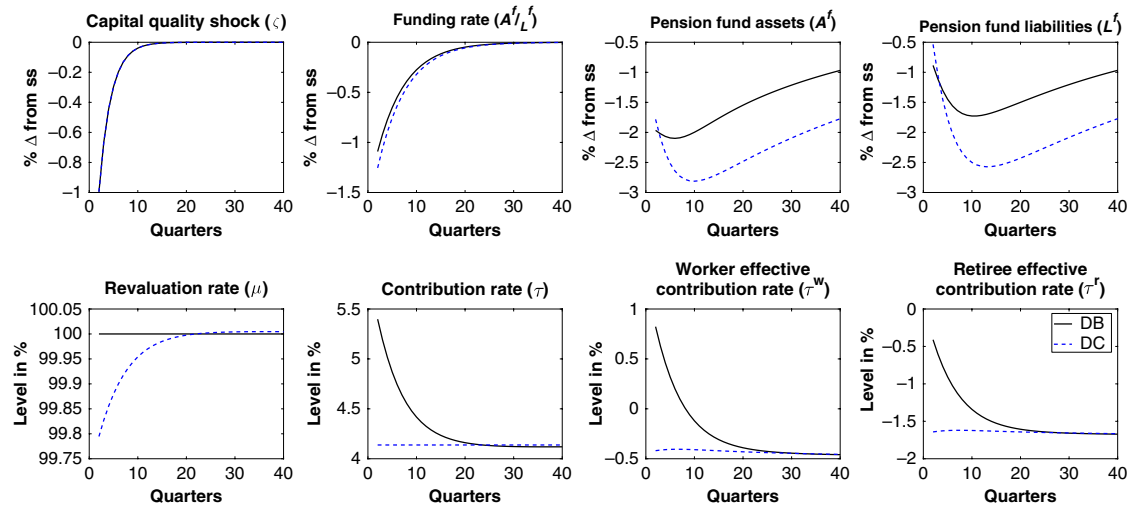

FigURE 1. Pension fund restoration policy after a $1 \%$ capital quality shock in a NewKeynesian model with a real pension fund framework. DB is denoted by the solid black line, while DC is denoted by the striped blue line.

contribution rate of retirees stays negative. The costs to workers of participating in the mandatory pension fund are higher than the benefits and thus the workers subsidize the retirees to guarantee their pension wealth. Even though in the steady state the two pension funds are of equal size, in the recovery they are significantly different because the DB pension fund implements a restoration policy of amassing assets and the DC pension fund implements a restoration policy of cutting liabilities.

Figure 2 presents a plot of the key macroeconomic variables in the DB, DC, and Laissez-Faire economies. There are two forces counteracting each other in the DB system. On the one hand, since the pension fund contributions are levied as a fraction of labor income, the DB restoration policy distorts labor supply. On the other hand, since retirees have a higher MPCW, guaranteeing the value of previously accumulated pension wealth ensures that wealth is allocated to the group of individuals that, in the margin, exercises a stronger demand for consumption goods. This can be an important consideration in a demand-driven, New-Keynesian model. The numerical simulations indicate that the former effect is stronger than the latter effect. The labor supply distortions imply that the total wealth of workers is depressed, causing aggregate demand to fall. This process is exacerbated by the nominal rigidities which prevent the retail sector from adjusting the price of output appropriately. Since the retirees are outnumbered by workers, the effect of their higher MPCW is quantitatively unimportant for the determination of macroeconomic aggregates. As a result, aggregate output, consumption, investment, and capital are all lower compared to the DC and Laissez-Faire economies. Unsurprisingly, Figure 2 indicates that the DC economy behaves similarly to an economy without a pension fund. In a Laissez-Faire economy agents save for retirement through their private financial wealth which evaporates due to the adverse capital quality shock in a similar fashion as the writing off of previously 

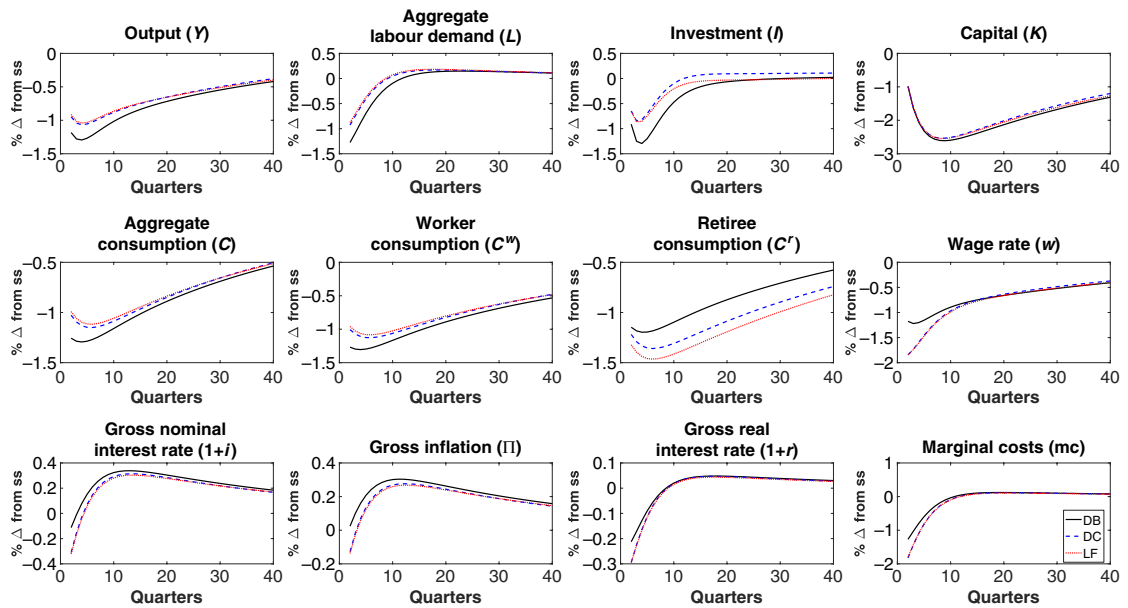

FIGURE 2. Effect of pension fund restoration policy after a $1 \%$ capital quality shock on macroeconomic variables in a New-Keynesian model with a real pension fund framework. DB is denoted by the solid black line, while DC is denoted by the striped blue line, and Laissez-Faire is denoted by the dotted red line.
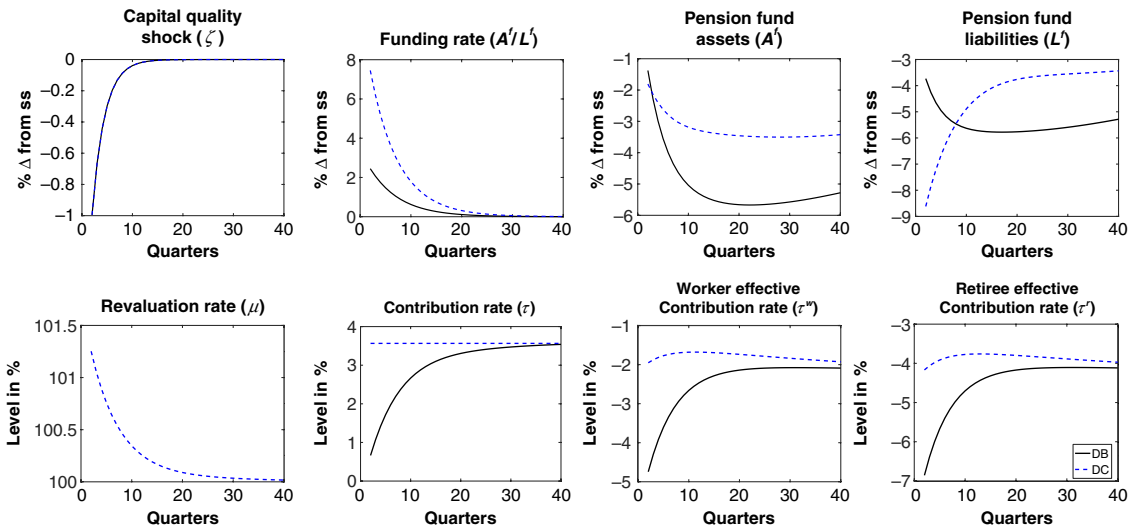

FigurE 3. Pension fund restoration policy after a $1 \%$ capital quality shock in a NewKeynesian model with a nominal pension fund framework. DB is denoted by the solid black line, while DC is denoted by the striped blue line.

accumulated pension wealth under the DC pension fund. However, since the accumulated pension wealth is written down gradually over time, retiree consumption is higher, coming at the expense of worker consumption, in the DC economy than in the Laissez-Faire economy.

3.2.2. Nominal pension fund accounting framework. Figure 3 highlights that the adverse capital quality shock actually leads to a funding surplus for the pension 

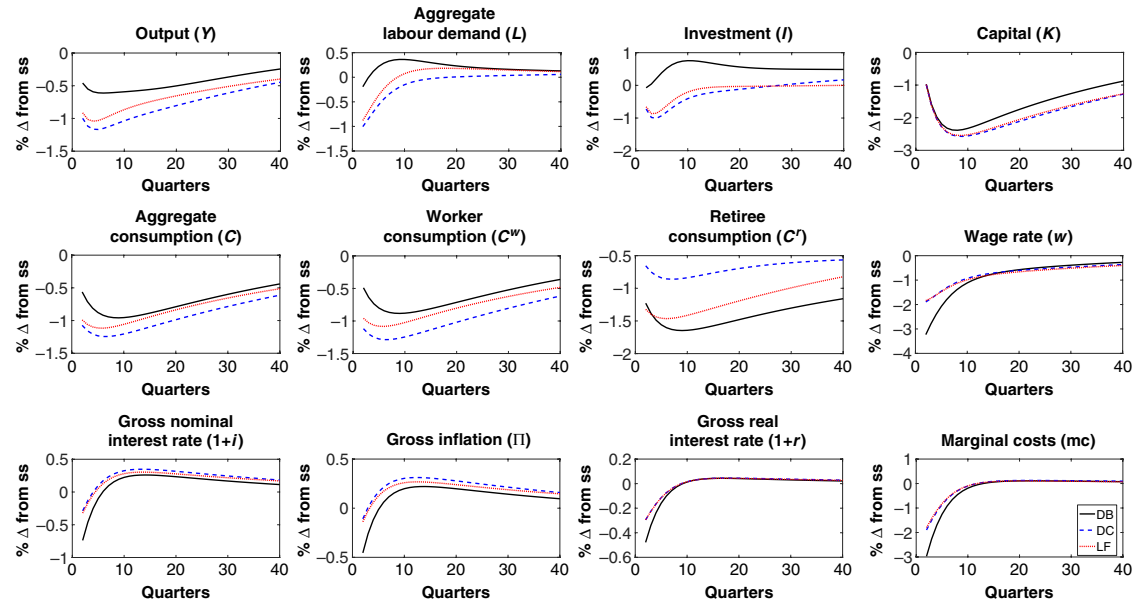

FIGURE 4. Effect of pension fund restoration policy after a $1 \%$ capital quality shock on macroeconomic variables in a New-Keynesian model with a nominal pension fund framework. DB is denoted by the solid black line, while DC is denoted by the striped blue line, and Laissez-Faire is denoted by the dotted red line.

fund in the nominal accounting framework. This is predominantly explained by the movement of the nominal interest rate in response to the unexpected shock and its effects on the liabilities of the pension fund. As in the real pension fund framework, the value of the assets of the fund is depressed by roughly $2 \%$ on impact. However, the value of the liabilities drops roughly $4 \%$ and $9 \%$ in the DB and DC economy, respectively. While in the short term the shock causes the price level to decrease, inflation picks up in the medium term as the economy recovers. Since the pension fund issues nominal promises to fund participants under this accounting framework, the ensuing inflation drives down the value of the fund liabilities substantially. ${ }^{11}$ This holds especially for the DC economy which is characterized by a higher inflation rate and a higher nominal interest rate compared to the DB economy. Since the pension fund faces a funding surplus, it implements a restoration policy which distributes welfare gains over different groups of individuals and cohorts. The DC pension fund increases the revaluation rate which offsets the loss of previously accumulated pension wealth. While the liabilities of the DB pension fund are decreasing in the short term due to the increasing path of the nominal interest rate, the liabilities of the DC pension fund recover quickly due to the marking up of previously accumulated pension wealth. The DB pension fund instead lowers the contribution rate and thus makes the accrual of new pension wealth relatively cheap. ${ }^{12}$ The plots of the effective contribution rates highlight this.

Figure 4 presents a plot of the key macroeconomic variables in the DB, DC, and Laissez-Faire economies. The cheap accrual of new pension wealth under the DB pension system implies that labor supply is subsidized. As a result, the economic 
downturn is mitigated compared to the DC and Laissez-Faire economies. The comparatively high labor supply leads to a lower wage rate and marginal cost, meaning that the retail firms that can change their prices set a lower reset price. This in turn leads to a lower inflation rate and nominal interest rate along the adjustment path and explains why the liabilities of the pension fund do not fall as much with a DB pension fund as with a DC pension fund. ${ }^{13}$ We conclude that a rather small adverse capital quality shock of $1 \%$ can have sizeable effects on the finances of a nominally defined pension fund, especially when the pension fund introduces an implicit subsidy or tax on labor supply which influences the pricing decisions of retail firms and in turn the financial position of the pension fund. Since retirees have a lower productivity compared to workers, it is difficult for them to accumulate sufficient additional pension wealth to offset the evaporation of their previously accumulated pension wealth. Therefore, retirees consume less under a DB system compared to a DC system, while the opposite is the case for workers. The effect of the labor supply distortion of the DB pension fund again outweighs the effect of the higher MPCW of retirees. While the DC and the Laissez-Faire economy behave similarly under the real accounting framework, we observe considerable differences between the two under the nominal accounting framework. Figure 3 shows that the effective contribution rate of workers increases with the DC pension fund, meaning that the labor supply of workers is distorted downwards. This stems from the fact that accumulating additional pension wealth is less attractive due to the relatively high level of the inflation rate. Workers are affected negatively not only by the implicit tax on labor supply, but also by the fact that their previously accumulated pension wealth is marked up in the first periods after the shock and afterwards, as inflation picks up, written down again. Retirees on the other hand are less reliant on their labor income and, due to their short remaining lifetime, benefit from receiving more pension benefits in the initial periods after the adverse capital quality shock.

\subsection{Welfare Effects of Pension Fund Restoration Policy}

We now turn to an assessment of the welfare effects of the various forms of pension fund restoration policy to see which pension fund system each group of individuals prefers. The equivalent variation $E V^{z}$ measures the lump-sum transfer a group of individuals with labor market status $z \in\{w, r\}$, initial private savings $A_{t-1}^{z}$, and pension entitlements $B_{t}^{z}$ must receive under scenario 1 to obtain the same utility as in scenario 0 . That is, the equivalent variation between scenario 0 and 1 is implicitly defined by

$$
V_{t}^{z}\left(A_{t-1}^{z, 1}+\frac{E V^{z}}{1+r_{t}^{1}}, B_{t}^{z, 1}, \Gamma_{t}^{1}\right)=V_{t}^{z}\left(A_{t-1}^{z, 0}, B_{t}^{z, 0}, \Gamma_{t}^{0}\right), z \in\{w, r\},
$$

where $\Gamma_{t}^{i}$, a scenario $i$ at period $t$, denotes all relevant aggregate information on factor prices and pension fund restoration policy from period $t$ onwards. ${ }^{14}$ Condition (25) highlights that total consumption is linear in total lifetime wealth, 
TABLE 4. Welfare effects of switching from a DB pension fund to a DC pension fund in various model environments after an adverse shock to capital quality of $1 \%$. Measured as an equivalent variation showing the transfer of wealth as a percentage of steady-state yearly output necessary for indifference between the two pension fund arrangements.

\begin{tabular}{lccc}
\hline Group of individuals & Real business cycle & $\begin{array}{c}\text { New-Keynesian } \\
\text { real framework }\end{array}$ & $\begin{array}{c}\text { New-Keynesian } \\
\text { nominal framework }\end{array}$ \\
\hline Retirees alive at $t=1$ & $-0.44 \%$ & $-0.41 \%$ & $+1.45 \%$ \\
Workers alive at $t=1$ & $-0.14 \%$ & $+0.11 \%$ & $-0.36 \%$ \\
Workers born after $t=1$ & $+0.07 \%$ & $+0.13 \%$ & $-0.36 \%$ \\
Total & $-0.51 \%$ & $-0.17 \%$ & $+0.73 \%$ \\
\hline
\end{tabular}

and condition (26) highlights that the indirect lifetime utility is linear in total consumption. We use this to calculate the equivalent variation:

$$
\begin{aligned}
& E V_{t}^{z}\left(A_{t-1}^{z, 0}, A_{t-1}^{z, 1}, B_{t}^{z, 0}, B_{t}^{z, 1}, \Gamma_{t}^{0}, \Gamma_{t}^{1}\right)= \\
& \frac{V_{t}^{z}\left(A_{t-1}^{z, 0}, B_{t}^{z, 0}, \Gamma_{t}^{0}\right)-V_{t}^{z}\left(A_{t-1}^{z, 1}, B_{t}^{z, 1}, \Gamma_{t}^{1}\right)}{\frac{\partial V_{t}^{z}\left(A_{t-1}^{z, 1}, B_{t}^{z, 1}, \Gamma_{t}^{1}\right)}{\partial A_{t-1}^{z,}\left(1+r_{t}^{1}\right)}}, z \in\{w, r\} .
\end{aligned}
$$

Let time period 0 denote the steady-state period and period 1 denote the period in which the adverse capital quality shock materializes. Additionally, DC denotes the scenario of the DC economy and DB denotes the scenario of the DB economy. We then consider the equivalent variations of the following three groups of individuals.

\begin{tabular}{lc}
\hline Group of individuals & Equivalent variation \\
\hline Retirees alive at $t=1$ & $E V_{1}^{r}\left(A_{0}^{r}, A_{0}^{r}, B_{1}^{r, D C}, B_{1}^{r, D B}, \Gamma_{1}^{D C}, \Gamma_{1}^{D B}\right)$ \\
Workers alive at $t=1$ & $E V_{1}^{w}\left(A_{0}^{w}, A_{0}^{w}, B_{1}^{w, D C}, B_{1}^{w, D B}, \Gamma_{1}^{D C}, \Gamma_{1}^{D B}\right)$ \\
Workers born after $t=1$ & $\sum_{i=2}^{\infty} \prod_{j=2}^{i}\left(\frac{1}{1+r_{j}^{D B}}\right)(1-\omega) E V_{i}^{w}\left(0,0,0,0, \Gamma_{i}^{D C}, \Gamma_{i}^{D B}\right)$ \\
\hline
\end{tabular}

For ease of interpretation, we express the equivalent variations as a share of yearly steady-state output. Table 4 depicts the welfare effects of switching from a DB pension fund to a DC pension fund in the period in which the adverse capital quality shock materializes for the baseline calibration and various model setups. ${ }^{15}$ In the real business cycle model, all individuals alive at period $t=1$ prefer a DB pension fund over a DC pension fund, while the future generations prefer the opposite. However, the desirability of a DB pension fund arrangement diminishes in a New-Keynesian environment where aggregate demand becomes important. While it is unsurprising that the group of retirees prefers a DB pension fund in 
TABLE 5. Welfare effects of switching from a DB pension fund to a DC pension fund in various model environments after a positive shock to capital quality of $1 \%$. Measured as an equivalent variation showing the transfer of wealth as a percentage of steady-state yearly output necessary for indifference between the two pension fund arrangements.

\begin{tabular}{lccc}
\hline Group of individuals & Real business cycle & $\begin{array}{c}\text { New-Keynesian } \\
\text { real framework }\end{array}$ & $\begin{array}{c}\text { New-Keynesian } \\
\text { nominal framework }\end{array}$ \\
\hline Retirees alive at $t=1$ & $+0.44 \%$ & $+0.43 \%$ & $-1.37 \%$ \\
Workers alive at $t=1$ & $+0.15 \%$ & $-0.04 \%$ & $+0.14 \%$ \\
Workers born after $t=1$ & $-0.07 \%$ & $-0.12 \%$ & $+0.31 \%$ \\
Total & $+0.52 \%$ & $+0.27 \%$ & $-0.92 \%$ \\
\hline
\end{tabular}

the real accounting framework, all workers now prefer the DC pension fund. To workers, the adverse labor supply distortions in the DB pension fund outweigh the positive effect of allocating more wealth to the group of individuals with the highest MPCW in the margin. Under the nominal accounting framework, the adverse capital quality shock depresses the value of accumulated pension wealth to the extent that retirees prefer the pension funding surplus to be paid out through increases in the valuation of previously accumulated pension wealth rather than through discounts on the accumulation of new pension wealth. Conversely, since workers are still active on the labor market and have relatively less dependence on accumulated pension wealth, workers prefer the pension funding surplus to be distributed through lower contribution rates.

Table 4 highlights that there is no preferred pension fund arrangement. Each system distributes welfare losses or gains over different groups of individuals and therefore there is no unanimous agreement between workers, retirees, and future generations about optimal pension fund design. ${ }^{16}$ The sum of the equivalent variations indicates that in a real accounting framework a DB pension fund is preferred and in a nominal accounting framework a DC pension fund is preferred. However, the sum is close to zero and furthermore depends on the rate used to discount the equivalent variations of future generations and the welfare weights attached to different groups of individuals. For simplicity we weigh each group equally and discount with the real interest rate, but one could make sensible arguments for different welfare weights and discount factors. Nevertheless, the welfare effects allow us to draw a consistent conclusion: when the pension fund faces a deficit, retirees prefer the labor market to be distorted and the value of their pension wealth to be guaranteed while workers prefer the opposite. When the pension fund faces a surplus, retirees prefer that the value of their pension wealth is marked up and that the accrual of new pension wealth is relatively expensive while workers prefer the opposite. ${ }^{17}$

Table 5 shows the welfare effects of a positive capital quality shock. The welfare effects in a real business cycle model have the opposite sign of a negative capital quality shock, but the New-Keynesian nominal rigidities lead to 
asymmetry. For instance, when an adverse shock materializes in an inflationindexed system, workers have a strong preference for switching to DC. After a positive capital quality shock of equal size, workers have a weaker preference for sticking with DB. ${ }^{18}$ Inspection of the impulse responses indicates that labor supply is depressed more after negative shocks than it is promoted after positive shocks. We relate this asymmetric response to the literature on pension fund design. Since other papers have not considered nominal rigidities, we compare their findings to the inflation-indexed pension funds that are studied here. Bonenkamp and Westerhout (2014) and Draper et al. (2017) conclude for DB pension funds that the welfare gain from intergenerational risk-sharing dominates the cost of labor supply distortions, which is consistent with our findings in a real business cycle model. Since the intergenerational risk-sharing allows future generations to take advantage of earlier realizations of the equity premium, a DB pension fund increases the mean consumption level of fund participants. Despite the higher resulting standard deviation of consumption, agents ex ante prefer DB pension funds over DC pension funds. Our findings in Tables 4 and 5 indicate that nominal rigidities cause workers to be negatively affected by adverse shocks, while workers are less positively affected by positive shocks. Compared to the real business cycle model, with a New-Keynesian production specification in Bonenkamp and Westerhout (2014) and Draper et al. (2017) the DB pension fund would be associated with a lower mean consumption level of workers and a higher standard deviation. While our perfect foresight setup does not allow for a comprehensible assessment of the benefits of intergenerational risk-sharing, the results dampen the appeal of DB pension funds.

\section{CONCLUSION}

This paper has provided an assessment of the business cycle effects and distributional implications of pension fund restoration policy by extending a canonical New-Keynesian dynamic general equilibrium model with a tractable demographic structure and a flexible pension fund framework. This model is used to investigate how the economy responds to an unexpected Gertler and Karadi (2011)-type capital quality shock when financial adequacy is restored by revaluing previously accumulated pension wealth (DC) or changing the pension fund contribution rate on labor income (DB). The main result of the paper is that due to nominal rigidities inflation-indexed DB pension funds (which are closest in design to the pension funds that have been studied in environments without nominal rigidities) significantly distort labor supply decisions and exacerbate economic fluctuations. Additionally, they transmit capital quality shocks asymmetrically: after an adverse shock workers are negatively affected while workers are less positively affected by positive shocks. The intergenerational risk-sharing literature, which has abstracted from nominal rigidities and distortions that materialize at a business cycle frequency, thus overstates the welfare improvement of inflationindexed DB pension funds by understating their potential for distorting labor 
supply. The general consensus in favor of DB pension funds in the literature on pension fund design is mirrored by the implemented restoration policies of Dutch pension funds. de Haan (2015) shows that underfunded Dutch pension funds consider contribution increases first, not indexing previously accumulated pension wealth second, and cuts to pensions only as a last resort. Our results indicate that the preference ordering of Dutch pension funds exacerbates economic fluctuations and might not be optimal from a welfare perspective. The results of this paper can also be related to the wider issue of commitment and stability in pension funds. As pointed out by Gollier (2008), maintaining intergenerational risk-sharing through pension funds after successive poor capital market performances requires strong government enforcement because younger generations will want to switch to individual pension systems. This becomes even more of a concern in a NewKeynesian setting where adverse capital quality shocks hit workers harder than positive ones. For a holistic welfare perspective on pension fund system design, however, the distortions and risk-sharing properties of pension fund systems have to be considered jointly. While the existing literature underestimates the importance of labor supply distortions, this paper does not consider the risk-sharing properties of different pension fund systems. This is an avenue we aim to explore in future research.

\section{NOTES}

1. The assumption of a "large" number of retirees and workers ensures that the contributions of a single agent have negligible effects on the financial position of the pension fund. Mandatory participation guarantees that the pension fund does not collapse in case of underfunding or overfunding. Beetsma et al. (2013) show that newly born workers would not want to participate in case the pension fund is underfunded as they would have to help restore funding adequacy, while van Bommel and Penalva (2012) show that older agents have an incentive to block newly born workers from participating in case the pension fund is overfunded so as to capture the funding surplus for themselves.

2. Note that in reasonable scenarios $\frac{1+r_{t+1}-v}{1+r_{t+1}}>0$.

3. The state variable $b_{t}^{z}$ contains the time subscript $t$ as $b_{t}^{z}$ can depend on the inflation $\Pi_{t}$ in the nominal accounting framework. Additionally, recall that $a_{t-1}^{z}$ is written in end-of-period notation, but that $b_{t}^{z}$ is written in beginning-of-period notation.

4. We allow retirees to supply labor and to accumulate additional pension benefits when retired, making the term "retiree" a relatively poor descriptor. Allowing retirees to continue to be active on the labor market makes the decision problem of retirees conveniently similar to the one of workers. Retirees will be less productive than workers and we will parameterize the productivity parameter such that the labor supply of retirees is close to zero.

5. The preference class ensures that we do not have to keep track of the period in which agents are born and in which period agents become retired. We can instead consider the groups of workers and retirees as a collective rather than comprised of a range of agents born in different periods. This keeps the state-space of the model small and simplifies aggregation.

6. This specification of the budget constraint assumes that the retiree was retired already in the previous period. Kara and von Thadden (2016) show that this characterization is sufficient to derive the aggregate behavior of retirees and workers.

7. In our calibration it will hold that $\Omega_{t}>1, \forall t$.

8. Calculated using data gathered from the OECD.Stat database. 
9. The OECD.Stat database reports that the average labor force participation rate among retirees aged 65 or above in OECD countries was 0.145 in 2016.

10. We solve for the equilibrium of the model using Dynare. Since we consider a perfect foresight model, the solution does not require linearization and instead is fully nonlinear.

11. Note that the inflation is not caused by a jump in the risk premium since we consider a model without aggregate risk.

12. This explains why the assets of the pension fund drop by roughly $5.5 \%$ in the DB case. The fund draws down its assets because it collects less contributions while it continues to fulfill its pension promises to retirees.

13. Figure 2 shows that the opposite is the case under the real accounting framework. However, the pension fund finances are unaffected by the inflation rate in the real accounting framework and thus the higher inflation rate in the DB case does not affect the restoration policy of the pension fund.

14. Note that the equivalent variation is not necessarily symmetric in the environments. Also note that we do not implement the wealth transfers, but consider the equivalent variations to be useful hypotheticals to assess the relative attractiveness of pension fund arrangements.

15. The welfare effects of the real business cycle model are obtained by switching off the NewKeynesian elements described in the model section.

16. This also holds for switching from a DB pension fund to a hybrid pension fund that combines the restoration policy of a DC and DB pension fund by using both the revaluation and contribution instrument to close the funding gap. As the fraction of the funding gap closure that stems from the revaluation instrument increases, the welfare effect of each group becomes monotonically stronger.

17. To test the robustness of our findings, we calculate the welfare effects for different values of the intertemporal elasticity of substitution, the size of the pension fund, and the closure speed of the funding gap. The results are reported in Table 6 in Supplementary Appendix D.

18. This also holds for shock sizes different than $1 \%$.

\section{SUPPLEMENTARY MATERIAL}

To view supplementary material for this article, please visit https://doi.org/10. 1017/S1365100518001049.

\section{REFERENCES}

Beetsma, R. M. W. J. and A. L. Bovenberg (2009) Pensions and intergenerational risk-sharing in general equilibrium. Economica 76, 364-386.

Beetsma, R. M. W. J. and W. E. Romp (2016) Intergenerational risk sharing. In: J. Piggott and A. Woodland (eds.), Handbook of the Economics of Population Aging, pp. 311-380. Amsterdam: North-Holland.

Beetsma, R. M. W. J., W. E. Romp and S. J. Vos (2013) Intergenerational risk sharing, pensions, and endogenous labour supply in general equilibrium. The Scandinavian Journal of Economics 115, $141-154$.

Blanchard, O. J. (1985) Debt, deficits, and finite horizons. Journal of Political Economy 93, 223-247.

Bonenkamp, J. and E. Westerhout (2014) Intergenerational risk sharing and endogenous labour supply within funded pension schemes. Economica 81, 566-592.

Calvo, G. A. (1983) Staggered prices in a utility-maximizing framework. Journal of Monetary Economics 12, 383-398.

Chen, D. H. J. and S. J. G. van Wijnbergen (2017) Redistributive Consequences of Abolishing Uniform Contribution Policies in Pension Funds. Tinbergen Institute Discussion Paper 2017-114/VI.

Christiano, L. J., M. Eichenbaum and C. Evans (2005) Nominal rigidities and the dynamic effects of a shock to monetary policy. Journal of Political Economy 113, 1-45. 
de Haan, L. (2015) Recovery Measures of Underfunded Pension Funds: Higher Contributions, No Indexation, or Pension Cuts? DNB Working Paper 485.

Draper, N., E. Westerhout and A. Nibbelink (2017) Defined benefit pension schemes: A welfare analysis of risk sharing and labour market distortions. Journal of Pension Economics and Finance 16, 467-484.

Farmer, R. E. A. (1990) RINCE preferences. The Quarterly Journal of Economics 105, 43-60.

Fernández-Villaverde, J. and J. F. Rubio-Ramírez (2006). A baseline DSGE model. Mimeo. Available at http://economics.sas.upenn.edu/ jesusfv/benchmark_DSGE.pdf.

Gertler, M. (1999) Government debt and social security in a life-cycle economy. Carnegie Rochester Conference Series on Public Policy, 61-110.

Gertler, M. and P. Karadi (2011) A model of unconventional monetary policy. Journal of Monetary Economics 58, 17-34.

Gollier, C. (2008) Intergenerational risk-sharing and risk-taking of a pension fund. Journal of Public Economics 92, 1463-1485.

Harrison, G. W., M. I. Lau and M. B. Williams (2002) Estimating individual discount rates in Denmark: A field experiment. American Economic Review 92, 1606-1617.

Kara, E. and L. von Thadden (2016) Interest rate effects of demographic change in a New-Keynesian life-cycle framework. Macroeconomic Dynamics 20, 120-164.

Laboul, A. (2010) Pension fund assets struggle to return to pre-crisis levels. OECD Pension Markets in Focus 7, 1-20.

Novy-Marx, R. and J. Rauh (2011) Public pension promises: How big are they and what are they worth? The Journal of Finance 66, 1211-1249.

OECD (2017) Pension Markets in Focus 2017. OECD Publishing. Available at http://www.oecd.org/ pensions/private-pensions/Pension-Markets-in-Focus-2017.pdf.

Romp, W. E. (2013) Procyclicality of Pension Fund Regulation and Behaviour. Netspar Discussion Paper 11/2013.

Treasury (2012) The Financial Crisis Response in Charts. Available at https://www.treasury.gov/ resource-center/data-chart-center/Documents/20120413_FinancialCrisisResponse.pdf.

van Bommel, J. and J. Penalva (2012) The Governance of Perpetual Financial Intermediaries. LSF Research Working Paper Series 12-10. 